\title{
Dimensions of Spirituality in Personality Competence Christian Religious Education Teacher
}

\author{
Delipiter Lase \& Etty Destinawati Hulu \\ STT Banua Niha Keriso Protestan Sundermann Nias \\ piterlase@sttsundermann.ac.id
}

Received: dd mm yyyy/Accepted: dd mm yyyy/Published: mm yyyy

\begin{abstract}
This article discusses the dimensions of spirituality in the personal competence of Christian Religious Education (CRE) teachers. Spirituality is essential because the teaching that CRE teachers do aims to improve the spirituality of their students. He should have good spirituality so that he can be an example in his teaching. In this paper, the author explaining the essential values of spirituality that must be possessed by a CRE teacher in order to fulfill his calling as someone who has a profession as a teacher. To arrive at this goal, the authors develop the essential values of spirituality by conducting literature studies and content analysis methods. Based on a search from various sources, including the nature of spirituality, according to Christianity, the author explains the essential spiritual values that must be possessed by a CRE teacher. The essential values of spirituality are grouped into two dimensions, namely the personal dimension and the relational dimension.
\end{abstract}

Keywords: spirituality, Christian religious education teacher, personality competence

\section{Introduction}

In the school environment, a Christian religious education teacher is not only expected to be a good teacher; he also tends to be able to play a role like a clergyman. Schools often assigned CRE teachers the burden of being preachers in religious activities in the school environment, handling various social activities in the scope of the big family of the school, and become a school advisor in decision making. The expectations of a CRE teacher are high; he is required to be able to perform various roles and have a high spirituality that can see in his attitude and behavior. Spirituality is one of the essential aspects that must be possessed by him because the task of educating is not just mechanical work but facing the challenges of pluralism of values, beliefs, and spirituality. Even more, the spirituality of a CRE teacher becomes imperative because the teaching that he does himself aims to improve the 
spirituality of students. He should have good spirituality so that they can be role models in their teaching.

The spirituality of someone who teaches the word of God has been emphasized in Titus 2: 7-8 "In all things shewing thyself a pattern of good works: in doctrine shewing uncorruptness, gravity, sincerity, sound speech, that cannot be condemned; that he that is of the contrary part may be ashamed, having no evil thing to say of you." Here Paul advised Titus, who was commissioned on the island of Crete, to be a role model of good deeds according to the word of God that he taught. Titus is required to live first according to the word of God that he taught before teaching others. Exemplary is a practical act of the right attitude in life, which Titus must show, and everyone can observe.

Everyone hopes that religious education teachers have high spirituality. However, in some cases, we found that CRE teachers only transfer knowledge to students, but do not demonstrate exemplary spirituality through attitudes and behavior. This difference occurs for various reasons; among them, they have not yet realized that to display useful personal competence, a CRE teacher needs to have good spirituality. CRE teachers often see themselves the same as other subject teachers. Not all CRE teachers can interpret Christian faith, become shepherds for their students, and serve as evangelists. This fact shows that the values of spirituality have not been fully internalized in CRE teachers.

\section{Literature Review}

Several people interpret spirituality in a narrow definition and are limited to religious activities. Interpret spirituality as limited to the actions of those who meditate in lonely and unusual places. There is also a view that people who diligently worship and engage in various religious activities are spiritual; assume that people who have supernatural abilities are people who have a high degree of spirituality. The servants of God, such as priests, religious scholars, monks, must be spiritual people.

According to Rahmiati Tanudjaja, several indicators that are often used by Christians today to measure one's spirituality, i.e., one's involvement in activities and various social services; the appearance of supernatural phenomena through his life; stay away from worldly matters; and using Christian attributes, for example, people who always carry a Bible, wear accessories, or always listen to Christian songs, are considered to be more in love with God than those who do not wear 
them. ${ }^{1}$ However, the above measure cannot be said to be an appropriate benchmark because true spirituality does not focus on superficial religious activities and bases itself on the order of moral values and the obligations in them.

As a result of this narrow and limited understanding, the notion of spirituality is shifting and increasingly unclear. It is because there are people who are active in religious activities that have bad daily behavior, and vice versa, also those who are ordinary in following religious activities have good spirituality. Even this closed and limited understanding does not cause deviant behavior, for example when acts of terrorism by detonating bombs in houses of worship or public places known as 'jihad' are believed to be forms of spirituality; or when the act of stealing money and then distributing it to the needy is considered a spiritual act. Therefore, spirituality must be understood broadly.

Over the last few decades, the term spirituality has entered the common language as an alternative way to describe our search for transcendence. In English, "spiritual" is a term used to distinguish church life in a natural or materialistic way. ${ }^{2}$ In the 19th century, "spirituality" was not a commonly used term, and "Spiritualism" referred to contact with spirits and other psychic phenomena. In contemporary usage, this term has several common meanings, ${ }^{3}$ and definitions in scientific literature also vary. These differences reflect the fact that spirituality is a broad term that encompasses various domains of meaning that may differ among various cultural, national, and religious groups. ${ }^{456}$ Today this term is often used to indicate the experience and personal side of our

${ }^{1}$ Rahmiati Tanudjaja, “Anugerah Demi Anugerah Dalam Spiritualitas Kristen Yang Sejati,” Veritas, no. 2 (October) (2002): 171-182.

2 Ana-María Rizzuto, "Psychoanalytic Considerations about Spiritually Oriented Psychotherapy.," in Spiritually Oriented Psychotherapy. (Washington: American Psychological Association, 2005), 31-50, http://content.apa.org/books/10886-002.

${ }^{3}$ Brian J. Zinnbauer et al., "Religion and Spirituality: Unfuzzying the Fuzzy," Journal for the Scientific Study of Religion 36, no. 4 (December 1997): 549, https://www.jstor.org/stable/1387689? origin=crossref.

${ }^{4}$ Eugene C. Roehlkepartain et al., "Spiritual Development in Childhood and Adolescence: Moving to the Scientific Mainstream," in The Handbook of Spiritual Development in Childhood and Adolescence, ed. E. Roehlkepartain and P. King (2455 Teller Road, Thousand Oaks California 91320 United States: SAGE Publications, Inc., 2006), 1-15, http://sk.sagepub.com/reference/hdbk_childspiritdev/nl.xml.

${ }^{5}$ E. Lewis, "Posture as a Metaphor for Biblical Spirituality," in The Destructive Power of Religion: Violence in Judaism, Christianity and Islam, ed. J. Ellens, vol. 4 (Westport, CT: Praeger, 2004), 143-174.

${ }^{6}$ Masami Takahashi and Satoshi Ide, "Implicit Theories of Spirituality across Three Generations: A Cross-Cultural Comparison in the U.S. and Japan," Journal of Religious Gerontology (2003). 
relationship with the transcendent or sacred ${ }^{7}$ (cf. Peter C. Hill et al. ${ }^{8}$; Emmons \& Crumpler $^{9}$ ). Those who use the term in this way usually contrast with religion, which they narrowly defined as the organizational structure, practices, and beliefs of religious groups. ${ }^{10}$ On the other hand, theologians and practitioners of religion tend to prefer a less attractive definition of a strict separation between religion and spirituality. ${ }^{11}$ In their eyes, spirituality is the reality of religious life as experienced by adherents of tradition.

Philip Sheldrake, in Spirituality and History, defines spirituality as "the conscious human response to God that is both personal and ecclesial." 12 Eka Dharmaputra understands that spirituality is the spirit, soul, and passion. Spirituality ranks first on a scale of priorities. Like a church that has all kinds and everything: church buildings, priests, activities, finance, many activities, but without spirituality that is spirit, soul, enthusiasm, and passion, then all of that will turn into just a church routine.13 Meanwhile, Eliade stated that Christian spirituality is a Christian way of life, which is worship and the development of a relationship with Christ. ${ }^{14}$ It means that Christian spirituality is the result of the relationship between humans and Christ which is then manifested in the daily way of life of Christians who emulate Christ. A good relationship between humans and Christ will enable the person to behave well in his life, love his fellow man, and forgive.

Christian spirituality concerns the quest for a fulfilled and authentic Christian existence, involving bringing together of the fundamental ideas of Christianity and the whole experience of living

${ }^{7}$ James M. Nelson, Psychology, Religion, and Spirituality, ed. James M. Nelson (New York, NY: Springer New York, 2009), http://link.springer.com/10.1007/978-0-387-875736.

${ }^{8}$ Peter C. Hill et al., "Conceptualizing Religion and Spirituality: Points of Commonality, Points of Departure," Journal for the Theory of Social Behaviour (2000).

${ }_{9}^{9}$ Robert A. Emmons and Cheryl A. Crumpler, "Religion and Spirituality? The

Roles of Sanctification and the Concept of God," The International Journal for the Psychology of Religion 9, no. 1 (January 16, 1999): 17-24, http://www.tandfonline.com/doi/abs/10.1207/s15327582ijpr0901_3.

${ }^{10}$ Brian J. Zinnbauer, Kenneth I. Pargament, and Allie B. Scott, "The Emerging Meanings of Religiousness and Spirituality: Problems and Prospects," Journal of Personality (1999).

${ }^{11}$ Nelson, Psychology, Religion, and Spirituality.

${ }_{12}$ Philip Sheldrake, "Spirituality: A Brief History," in Statewide Agricultural Land Use Baseline 2015, 2nd ed. (Somerset, New Jersy: John Wiley and Sons, 2013), 23-46.

${ }^{13}$ Eka Darmaputera, Spiritualitas Siap Juang (Jakarta: BPK Gunung Mulia, 2011), 207.

${ }^{14}$ Mircea Eliade, The Encyclopedia of Religion, 3rd ed. (New York: Macmillan Publishing, 1986), 452. 
based on and within the scope of the Christian faith. ${ }^{15}$ McGrath's view implies that Christian spirituality can be understood as a way taken by Christians, both individually and in groups to deepen their experience with God, or to practice "God's presence." So that Christian spirituality is manifested in the form of prayers to God, personal reflection, praise, and worship to God through singing, meditation, and also through good living behavior as the fruits of the Spirit in the lives of Christians.

Meanwhile, Victor Tanja stated that Christian spirituality is an attitude of life that results in love, joy, peace, prosperity, patience, kindness, gentleness, and self-control. Christian spirituality is an expression of the attitude of life that always works because with that work, our lives bring others to life and bring good to all people who are God's fellow creatures.16 It shows that Christian spirituality is the attitude and way of life of Christians who bring good to others around them.

Within the academic sphere, spirituality (spiritual quotient) is discussed scientifically by Danah Zohar (a psychologist) and Ian Marshall (a physicist) in a book called SQ: Spiritual Intelligence - The Ultimate Intelligence (2000). The book discusses spiritual intelligence as a determining factor for the effectiveness of intellectual intelligence and emotional intelligence. The Zohar defines spiritual intelligence as intelligence to face and solve problems of meaning and value, namely intelligence to place our behavior and life in the context of a broader and richer meaning, intelligence to judge that someone's actions or way of life are more meaningful than others. SQ is the foundation needed to function IQ and EQ effectively. Even SQ is our highest intelligence. ${ }^{17}$

Here Zohar links SQ with IQ and EQ. High IQ enables someone to think, and EQ enables someone to decide to be right following the conditions they face, so SQ enables someone to decide whether he wants to be in a situation like that. So IQ and EQ work within the boundaries of the situation, while SQ enables someone to be able to change or improve the situation they face.

Margot Cairnes, an expert in education, in Tanudjaja provides a definition that confirms Zohar's statement by saying that SQ is a person's ability to ask questions, think creatively, change rules, work

${ }^{15}$ Alister E. McGrath, Christian Spirituality: An Introduction (Oxford: Blackwell Published, 1999), 2.

${ }^{16}$ Victor Tanja, Spiritualitas, Pluralitas, Dan Pembangunan Di Indonesia (BPK Gunung Mulia, 1996), 9.

17 Zohar \& Marshall and Jenny King, "SQ: Spiritual Intelligence: The Ultimate Intelligence," Psychology and Psychotherapy 75, no. January (2002): 116-117. 
effectively in situations that change beyond existing boundaries, penetrate obstacles. Existing obstacles and making innovation.18 Cairnes's opinion shows that spiritual intelligence is the ability of a person to change or improve a particular situation creatively and innovatively in order to be better.

It appears that people who have spiritual quotient can understand the feelings of others, can read explicitly and implicitly, can grasp the verbal and nonverbal language, can treat others well as he also wants to be treated well by others. His insights will lead him to behave and act according to the needs and demands of his environment. In other words, spiritual intelligence can help someone to respond to the demands of their environment appropriately. Also, it shows explicitly that spiritual quotient has a relationship with a person's belief in his Lord, or is inseparable from the religion that is believed.

Furthermore, in the view of Christianity, spirituality begins when a person believes and accepts Jesus as his personal Savior. That person is given power by God, as stated in the word of the Lord, "But as many as received him, to them gave he power to become the sons of God, even to them that believe on his name; which were born, not of blood, nor the will of the flesh, nor the will of man, but God" (John 1: 12-13). This verse explains that every believer is given power by God to become children of God who behaves and lives according to God's will. That attitude and way of life that is following God's will is called Christian spirituality.

From the view of the experts above, the author believes that that spirituality is a state or spiritual nature regarding the total relationship and obedience of someone who believes in God. The total relationship and obedience flow the spirit and encouragement in the person to behave, speak, and think according to the teachings/commands of God, he believes.

\section{Method}

To develop concepts relevant to the topic, the authors conducted a literature study obtained from books and scientific journals, research reports, scientific essays, theses and dissertations, encyclopedias and other printed and electronic sources. Furthermore, that in order to get precise characteristics of the discourse in the form of theories and concepts being studied, the authors use the content analysis method,

\footnotetext{
${ }^{18}$ Tanudjaja, “Anugerah Demi Anugerah Dalam Spiritualitas Kristen Yang Sejati.”
} 
which is a research technique to make inferences that can be replicated and valid data by paying attention to the context. ${ }^{19}$

\section{The Dimension of Spirituality in CRE Teacher Personality Competencies}

Before explaining the dimensions of spirituality in CRE teacher personality competencies, it is necessary first to understand the essence of Christian religious education.

Thomas Groome defines Christian Education as "a political activity with pilgrims in time that deliberately and intentionally attends with them to the activity of God in our present, to the Story of the Christian faith community, and to the Vision of God's Kingdom, the seeds of which are already among us." 20 "As the process whereby Christian learning takes place. It often involves "teaching, which enables practicing Christians to adopt and deepen their Christian beliefs, values, and dispositions to experience and act in a Christian way. It depends to a greater extent on how this process is adopted and practiced in different churches."2l George Albert Coe in Christopher Byaruhanga defines Christian religious education as "the systematic, critical examination and reconstruction of relations between persons, guided by Jesus' assumption that persons are of infinite worth, and by the hypothesis of the existence of God, the Great Valuer of persons." 22

In line with it, the authors argue that Christian religious education is teaching people to know who Jesus Christ is and have faith in Jesus Christ indeed. Thus CRE is to teach knowledge and the views, beliefs, dogmas, or theology that a person has about Jesus Christ. Religious education given should be a truth, which is under the corridor of God's word, which is the principle and fundamental. CRE is an essential tool in preparing someone to face the future. That is why the quality of teachers must always be improved. The increase is not only an increase in terms of theory, but the CRE teacher must also experience an increase in

${ }^{19}$ Klaus Krippendorff, Content Analysis: An Introduction to Its Methodology (Second Edition), SAGE Publications, 2004.

${ }^{20}$ Thomas H. Groome, Christian Religous Education: Sharing Our Story and Vision (San Francisco: Jossey-Bass Publishers, 1980), 25.

21 "What Is Christian Religious Education?," Essay, UK, last modified 2018, accessed December 31, 2019, https://www.ukessays.com/essays/religion/the-definitionof-christian-religious-education-theology-religion-essay.php?vref=l.

${ }^{22}$ Christopher Byaruhanga, Essential Approaches to Christian Religious Education, Learning and Teaching in Uganda (Geneva: Globethics.net, 2018), 41-42, https://www.globethics.net/documents/4289936/15469226/GE_Praxis_9_isbn97828893 12344.pdf/74888ec4-26a5-4bac-9fc0-068c23755eb6. 
spirituality, in the sense that he grows and lives according to what he teaches to his students.

According to Sidjabat, at least six theological foundations are essential elements in Christian religious education activities, namely (1) knowledge of God; (2) a view of the position and function of the Bible; (3) an introduction to Jesus Christ; (4) the Holy Spirit and His people; (5) humans, position and vocation; and (6) maturity. ${ }^{23}$

Based on the description above, the nature of Christian religious education can be understood more broadly than just teaching, nurturing, socializing, and enculturation. Christian religious education as an educational concept has assumptions about the efforts made consciously, systematically, and continuously. However, education is devoted to the religious dimension of human life. Furthermore, the addition of the word 'Christian' to the term confirms that education in the religious dimension of human life is carried out from the perspective of Christianity, with the context and content of Christianity.

Who is the CRE teacher? In the Republic of Indonesia Law No. 14/2005 concerning teachers and lecturers, it explains that teachers are professional educators who educate, teach, guide, direct, train, assess, and evaluate students in early childhood education in the paths of formal education, primary and secondary education. Thus it can be understood that the teacher is someone who has the expertise, skills, and skills which carry out their duties professionally at formal education starting from the lowest level to the level of secondary education.

It shows a teacher is a person who has more knowledge, so he is smarter than his students. The teacher has the skills to give instructions in the teaching-learning process and educate. The teacher teaches through his mouth, through the expression on his face, through the movement of his limbs, through sign language either consciously or unconsciously, through his attitude and nature: polite, friendly, caring, responsive, assertive, conscientious, neat, clean, brave, disciplined, smart, careful, dexterous, skilled, and so on. Teachers are imitated and encouraged by students. Therefore the teacher should ideally be an example for his students. The Apostle Paul wrote a letter to Timothy that is being an example in terms of words means the teacher must say friendly, clear and accurate; be a role model in behavior, meaning teachers must behave, act ethically, and be polite; be an example of love, meaning that teachers must love, be patient, and be willing to sacrifice for their students; an example of loyalty, means the teacher must be

23 B. S Sidjabat, Mengajar Secara Profesional : Mewujudkan Visi Guru Profesional (Yayasan Kalam Kudus, 2009). 
diligent in teaching, diligently correcting the work of students; and be a role model in the sanctity of life, means the teacher must maintain his faith, holiness himself, and keep away from various despicable acts.

Therefore, CRE teachers are professional educators who have assignments in Christian religious education, not entirely different from the teachers in general, except for their task fields. However, as a CRE teacher, there are essential differences in terms of spirituality, faith, love, and preaching to students. To reinforce this statement, Ionel Ene and Iuliana Barna presented the specificity of intervention for the religious teacher as follows. ${ }^{24}$

"First, qualification - theological seminary, B.A. in theology, teachers' training certificate; general and specific competences; professional experience. Second, methods - not limited to formal teaching - promotes indirect influencing methods of stimulating faith and sensitivity. Third, objectives, the objective of teaching is mental knowledge, but especially spiritual knowledge, the development of faith, and sensitivity. Fourth, learning contents - praying and the study of the Bible is central to the teaching of religion; the class will not be reduced to teaching various information and facts. Fifth, curriculum - the teacher must use the same curriculum and the same materials for all the children in the class, but he must also be able to adapt to specific contexts and needs (specific needs of the students as an individual and social requirements, without deflecting from the ethical norms). Sixth, creativity - the teacher gives the student the chance to discover new things, to ask questions, to look for answers, and to get involved in various activities. Seventh, motivation - teaching religion is a profession chosen with both sensible and affective reasons, which is why the desire to open the students a path to spirituality through the formation of a faultless moral and social character is of the essence. Eighth, disciplinary methods - disciplinary methods should be applied at all times with love, as a prerequisite of the teacher-student relationship. They must be used given instructing children in what moral, religious and social behavior is concerned. Ninth, resources - the religion teacher does not use approved materials exclusively, and he must also create and diversify his resources. Tenth, evaluation - evaluation should be regarded by the children as a means of analyzing their activity, as a stage towards self-assessment, and not as a constraint. Eleventh, control - the teacher must be able to control a class made of 20 to 30 students permanently; he must promote a

${ }^{24}$ Ionel Ene and Iuliana Barna, "Religious Education and Teachers' Role in Students' Formation towards Social Integration," Procedia-Social and Behavioral Sciences 180 (May 2015): 30-35. 
communion of love and respect between the students, but also in the teacher-student relationship. Lastly, time - time spent with the children is not limited to class activities. The children take part in the religious service held at the church, or in various religious, social, philanthropic events in the life of the community. These are auspicious moments that valorize the children's religious education".

Furthermore, according to Homrighausen CRE teacher spirituality consists of three subcomponents of competence, namely: "having the power of spirituality that awakens teacher professionalism, has a calling spirit and has a mastery of God's word as a source of teaching material."25

In line with the opinion above and based on the literature review of spirituality, the author argues that the values of Christian spirituality in the personality of the CRE teacher can be described in two parts, namely the personal dimension and the relational dimension. Personal dimensions are matters relating to the person of the individual, while the relational dimension is matters relating to the relationship between individuals and each other.

If each dimension is explained the essence of spiritual values contained in it, the spiritual values that must be owned by a CRE teacher are as follows.

Table l: The spiritual values in personal dimension

\begin{tabular}{|c|c|c|}
\hline Dimension & Spiritual Values & Indicator \\
\hline \multirow[t]{2}{*}{$\begin{array}{l}\text { Personal } \\
\text { dimension }\end{array}$} & $\begin{array}{l}\text { A good relationship } \\
\text { with God }\end{array}$ & $\begin{array}{l}\text { - Be a role model for students in } \\
\text { establishing a relationship with God } \\
\text { through singing and prayer activities } \\
\text { (Acts 2: 43-47) } \\
\text { - Be a role model for students in terms } \\
\text { of fellowship and worship (Heb. } \\
\text { 10:25) } \\
\text { - Perform spiritual practices such as } \\
\text { meditation, devotion (Matt. 14: 13a; } \\
\text { Mark l:35). } \\
\text { - Recognize that the task as an } \\
\text { educator is the task of God's call in } \\
\text { his life }\end{array}$ \\
\hline & $\begin{array}{l}\text { Trust and accept } \\
\text { Jesus as his Savior }\end{array}$ & $\begin{array}{l}\text { - Dare to acknowledge Jesus as his } \\
\text { Savior and encourage his students to } \\
\text { accept and acknowledge Jesus as }\end{array}$ \\
\hline
\end{tabular}

${ }^{25}$ E.G. Homrighausen and I.H. Enklaar, Pendidikan Agama Kristen (Jakarta: BPK Gunung Mulia, 2015), 180-181. 


\begin{tabular}{|c|c|}
\hline & $\begin{array}{l}\text { their personal Lord and Savior. } \\
\text { - Make Jesus an example in his life } \\
\text { and teaching }\end{array}$ \\
\hline Led by the Spirit & $\begin{array}{l}\text { - Have the spirit, soul, enthusiasm in } \\
\text { carrying out teaching duties } \\
\text { - Wisdom in dealing with various } \\
\text { problems, both personal and related } \\
\text { issues as teachers (Isaiah 33: 6; Eph. } \\
\text { l:17) } \\
\text { - Diligently carrying out duties as a } \\
\text { teacher } \\
\text { - Confidence }\end{array}$ \\
\hline $\begin{array}{l}\text { Have a life centered } \\
\text { on the Triune God }\end{array}$ & $\begin{array}{l}\text { Making the Triune God the center of } \\
\text { his teaching }\end{array}$ \\
\hline $\begin{array}{l}\text { Stick to the } \\
\text { teachings of the } \\
\text { Bible }\end{array}$ & $\begin{array}{l}\text { - Making the Bible the basis of his } \\
\text { teaching (2 Tim. 3:16) } \\
\text { - Being able to interpret God's word } \\
\text { according to the hermeneutic } \\
\text { principle }\end{array}$ \\
\hline $\begin{array}{l}\text { Have confidence in } \\
\text { the God he believes }\end{array}$ & $\begin{array}{l}\text { - Dare to bear testimony of faith and } \\
\text { encourage students to bear } \\
\text { testimony of their faith } \\
\text { - Encourage students to entrust their } \\
\text { lives and struggle into God's hands } \\
\text { - Encourage students to believe that } \\
\text { God can complete his struggle }\end{array}$ \\
\hline $\begin{array}{l}\text { Maintain holiness } \\
\text { and sanctity of life }\end{array}$ & $\begin{array}{l}\text { - Keep away from things that are } \\
\text { contrary to the teachings of Christ } \\
\text { (Romans 13:13) } \\
\text { - Uphold the teachings and rules of } \\
\text { the church }\end{array}$ \\
\hline $\begin{array}{l}\text { Have a purpose in } \\
\text { life }\end{array}$ & $\begin{array}{l}\text { - Having a vision \& mission in his life } \\
\text { - Show the right direction for the lives } \\
\text { of students by giving advice, } \\
\text { reprimanding, criticizing, and } \\
\text { guiding (1 Pet. 2: 9; Mk 12: 29-30) } \\
\text { - Motivate students to study well } \\
\text { - Become a motivator for their } \\
\text { students' personal lives }\end{array}$ \\
\hline $\begin{array}{l}\text { Have a good } \\
\text { relationship with } \\
\text { fellow creatures } \\
\text { created by God }\end{array}$ & $\begin{array}{l}\text { - Have a good relationship with each } \\
\text { family member (1 Tim. 3: } 1-7 \text { ) } \\
\text { - Establish good collaboration with } \\
\text { others }\end{array}$ \\
\hline
\end{tabular}




\begin{tabular}{|c|c|}
\hline & $\begin{array}{l}\text { - Nurturing and preserving the } \\
\text { universe by being an example to } \\
\text { students and coworkers through } \\
\text { concrete actions (Gen. 1:28). }\end{array}$ \\
\hline Positive thinking & $\begin{array}{l}\text { - Not being prejudiced (suspicious) of } \\
\text { students and coworkers } \\
\text { - Able to take valuable lessons from a } \\
\text { failure } \\
\text { - Optimistic in his life }\end{array}$ \\
\hline
\end{tabular}

Table 2: The spiritual values in relational dimension

\begin{tabular}{|c|c|c|}
\hline Dimension & Spiritual Values & Indicator \\
\hline \multirow[t]{6}{*}{$\begin{array}{l}\text { Relational } \\
\text { dimension }\end{array}$} & Patient & $\begin{array}{l}\text { Able to deal with various student } \\
\text { behaviors (Col. 3: 12-13) }\end{array}$ \\
\hline & $\begin{array}{l}\text { Be flexible and } \\
\text { adjust to the } \\
\text { environment }\end{array}$ & $\begin{array}{l}\text { - Able to manage class well } \\
\text { - Be a friend to the students } \\
\text { - Respect colleagues } \\
\text { - Loyal to the leader } \\
\text { - Learning methods implemented } \\
\text { creatively and varied }\end{array}$ \\
\hline & Emotions are stable & $\begin{array}{l}\text { - Steadfast and persistent, do not give } \\
\text { up quickly, and self-introspection } \\
\text { - Optimistic, calm, tolerant and } \\
\text { logical }\end{array}$ \\
\hline & $\begin{array}{l}\text { Strong and resilient } \\
\text { in the face of } \\
\text { suffering and pain } \\
\text { Independent }\end{array}$ & $\begin{array}{l}\text { - Not easy to give up, complain, or } \\
\text { grumble } \\
\text { - Self-develop by expanding literation } \\
\text { by attending training, seminars or } \\
\text { workshops and reading various } \\
\text { sources related to their field of work } \\
\text { - Improve professional skills for } \\
\text { teaching in media (technology) } \\
\text { literation } \\
\text { - Work hard }\end{array}$ \\
\hline & Loyal & $\begin{array}{l}\text { - Complete the task to completion } \\
\text { - Not leaving work } \\
\text { - Ready to be placed or assigned } \\
\text { anywhere }\end{array}$ \\
\hline & Responsible & $\begin{array}{l}\text { - Taking risk } \\
\text { - Not to blame others } \\
\text { - Complete the task on time }\end{array}$ \\
\hline
\end{tabular}




\begin{tabular}{|c|c|}
\hline Joyful & $\begin{array}{l}\text { - Pleasant (1 Sam. 2:26) } \\
\text { - Beaming or not glum (Proverbs } \\
\text { 15:13) } \\
\text { - Able to convey words of comfort to } \\
\text { students who experience sadness (2 } \\
\text { Cor. 2: 7) }\end{array}$ \\
\hline $\begin{array}{l}\text { Peace and } \\
\text { prosperous }\end{array}$ & $\begin{array}{l}\text { - Not inciting or provoking students } \\
\text { with various issues (Gal. 5:12) } \\
\text { - Intercede for the troubled student } \\
\text { (Matt. 5: 9) } \\
\text { - Able to embrace all his students in } \\
\text { unity (John 17:21; Col. 3:14) } \\
\text { - Not to overload other people's } \\
\text { minds }\end{array}$ \\
\hline $\begin{array}{l}\text { Loving and } \\
\text { generous }\end{array}$ & $\begin{array}{l}\text { - Love his students (Leviticus 19:18; } \\
\text { Luke 10:27) } \\
\text { - Have sympathy and empathy for } \\
\text { their students } \\
\text { - Treat students non-discriminately } \\
\text { (Deut 16:20; Micah 6: 8) } \\
\text { - Can treat others as well as he wants } \\
\text { to be treated well by others }\end{array}$ \\
\hline $\begin{array}{l}\text { Ethical behavior } \\
\text { following Christian } \\
\text { values }\end{array}$ & $\begin{array}{l}\text { - Dress modestly and neatly } \\
\text { - Good words } \\
\text { - Do not utter obscenities or curse } \\
\text { - Do not speak harshly to hurt } \\
\text { - feelings or discourage students } \\
\text { - Polite or have good manners (1 Cor. } \\
\text { 14:40) }\end{array}$ \\
\hline
\end{tabular}

Internalization of Spiritual Values in CRE Teachers

Values that have been intact in someone will form a mindset in seeing the meaning of the reality of experience. These values can be from various aspects of religion, culture, social norms, and others. The meaning of this value is what colors the meaning and attitude of humans towards themselves, the environment, and the reality around them. Thus the process of internalization is a process that lasts throughout an individual's life; that is from the time he was born until the end of his life.

The development of student spirituality within the scope of the school should occur through an internalization process; this is because 
schools are a social system. "School, as a social system, describes schools as institutions and suggests a model of analysis that addresses the complex and often contradictory purposes of schooling." 26 The situation in schools is not much different from the situation in society. Schools have characteristics similar to those within the social system. The social institution called the school is a small society that has a culture. School culture and interaction between individuals within it will give birth to a social system.

Therefore, education within the scope of the school takes place through a process of internalizing values that is manifested through interactions between everyone in it. Through interaction, one will imitate the views, lifestyle, and spirituality of other colleagues. Of course, this is where it is demanded that leaders always try to make themselves transparent or observable, and open in front of the people they serve.

Here the teacher's role as an example and role model when interacting with fellow teachers and students is essential. He will be observed, but at the same time be observers of the process of interaction of people in the group. He becomes a facilitator who motivates or enables meaningful communication to occur correctly. He is a leader, but also a member of his group, who is needed and needs others. Correspondingly, he is required to demonstrate the value and attitude of life as a servant among his fellowmen as a form of his spirituality to the God he believes, as well as being the center of his teaching. So thus, a teacher can be said to be a living curriculum, because his whole life becomes a source of learning for his students.

It is in line with the Ono Niha (Nias) proverb that says "mangumaö daromali, mango'ou mbuabua," which means that theory can teach, but actions encourage others who see it take part in doing it. Therefore, if the CRE teacher wants his students to have good spirituality, then he must not only teach them with words but also with his actions.

\section{Conclusion}

CRE teachers are professional educators who have assignments in CRE subjects. What distinguishes it from the teacher in general lies in the dimensions of spirituality, affection, and preaching. Aside from being professional education, a teacher of Christian religious education has a

${ }^{26}$ Peter W. Cookson, "School as a Social System," in International Encyclopedia of the Social \& Behavioral Sciences: Second Edition, 2015. 
unique role as an interpreter of the Christian faith, being a shepherd for his students, and serving as an evangelist, who is responsible for the handover of each of his students to Jesus Christ.

Learning outcomes held by CRE teachers in the form of changes in each student in general and human literacy, in particular, will only be achieved maximally if the CRE teacher has a set of competencies, including personality competencies. To strengthen this personality competency, a CRE teacher must have good spirituality. The values of spirituality in personality competence will appear in the personal and relational dimensions in the implementation of tasks and their role as CRE teachers.

A teacher's real life is like an open book that can be read by everyone, including students. This aspect is interrelated with the student's assessment of the CRE teacher's personality, meaning that students will follow the example shown by him in general. Problems will arise if the example cannot be demonstrated. As a result, student assessments of teachers become less useful and can cause a decrease in the interest or motivation of students to grow in faith in God.

"Do not try to fix the students, fix ourselves first. The good teacher makes the poor student good and good student superior. When our students fail, we, as teachers too, have failed." ${ }^{27}$ This sentence state that a good teacher must first be better than his students. If he expects his students to be good, then he must be far better than them, and if he wants his students who are already good to be superior, then the teacher must be superior to them. When a student fails, it means that the teacher has failed to become a teacher.

\section{References}

Byaruhanga, Christopher. Essential Approaches to Christian Religious Education, Learning and Teaching in Uganda. Geneva: Globethics.net, 2018.

https://www.globethics.net/documents/4289936/15469226/GE_Pra xis_9_isbn9782889312344.pdf/74888ec4-26a5-4bac-9fc0068c23755eb6.

Collins, Marva. "The Outstanding Educator." Bleacherreport.Com. Last modified 2008. Accessed May 13, 2019.

${ }^{27}$ Marva Collins, "The Outstanding Educator," Bleacherreport.Com, last modified 2008, accessed May 13, 2019, https://bleacherreport.com/articles/53191-marva-collinsthe-outstanding-educator. 
https://bleacherreport.com/articles/53191-marva-collins-theoutstanding-educator.

Cookson, Peter W. "School as a Social System." In International

Encyclopedia of the Social e Behavioral Sciences: Second Edition, 2015.

Darmaputera, Eka. Spiritualitas Siap Juang. Jakarta: BPK Gunung Mulia, 2011.

Eliade, Mircea. The Encyclopedia of Religion. 3rd ed. New York: Macmillan Publishing, 1986.

Emmons, Robert A., and Cheryl A. Crumpler. "Religion and Spirituality?

The Roles of Sanctification and the Concept of God." The International Journal for the Psychology of Religion 9, no. 1 (January 16, 1999): 17-24.

http://www.tandfonline.com/doi/abs/10.1207/s15327582ijpr0901_3.

Ene, Ionel, and Iuliana Barna. "Religious Education and Teachers' Role in Students' Formation towards Social Integration." Procedia -Social and Behavioral Sciences 180 (May 2015): 30-35.

Groome, Thomas H. Christian Religous Education: Sharing Our Story and Vision. San Francisco: Jossey-Bass Publishers, 1980.

Hill, Peter C., Kenneth II. Pargament, Ralph W. Hood, Jr., Michael E. McCullough, James P. Swyers, David B. Larson, and Brian J. Zinnbauer. "Conceptualizing Religion and Spirituality: Points of Commonality, Points of Departure." Journal for the Theory of Social Behaviour (2000).

Homrighausen, E.G., and I.H. Enklaar. Pendidikan Agama Kristen. Jakarta: BPK Gunung Mulia, 2005.

Krippendorff, Klaus. Content Analysis: An Introduction to Its Methodology (Second Edition). SAGE Publications, 2004.

Lewis, E. "Posture as a Metaphor for Biblical Spirituality." In The

Destructive Power of Religion: Violence in Judaism, Christianity and Islam, edited by J. Ellens, 4:143-174. Westport, CT: Praeger, 2004.

McGrath, Alister E. Christian Spirituality: An Introduction. Oxford: Blackwell Published, 1999.

Nelson, James M. Psychology, Religion, and Spirituality. Edited by James M.

Nelson. New York, NY: Springer New York, 2009.

http://link.springer.com/10.1007/978-0-387-87573-6.

Rizzuto, Ana-María. "Psychoanalytic Considerations about Spiritually Oriented Psychotherapy.” In Spiritually Oriented Psychotherapy., 31-50. Washington: American Psychological Association, 2005. http://content.apa.org/books/10886-002.

Roehlkepartain, Eugene C., Peter L. Benson, Pamela Ebstyne King, and Linda M. Wagener. "Spiritual Development in Childhood and 
Adolescence: Moving to the Scientific Mainstream." In The Handbook of Spiritual Development in Childhood and Adolescence, edited by E.

Roehlkepartain and P. King, 1-15. 2455 Teller Road, Thousand Oaks California 91320 United States: SAGE Publications, Inc., 2006. http://sk.sagepub.com/reference/hdbk_childspiritdev/nl.xml. Sheldrake, Philip. "Spirituality: A Brief History." In Statewide Agricultural Land Use Baseline 2015, 23-46. 2nd ed. Somerset, New Jersy: John Wiley and Sons, 2013.

Sidjabat, B. S. Mengajar Secara Profesional : Mewujudkan Visi Guru Profesional. Yayasan Kalam Kudus, 2009.

Takahashi, Masami, and Satoshi Ide. "Implicit Theories of Spirituality across Three Generations: A Cross-Cultural Comparison in the U.S. and Japan." Journal of Religious Gerontology (2003).

Tanja, Victor. Spiritualitas, Pluralitas, Dan Pembangunan Di Indonesia. BPK Gunung Mulia, 1996.

Tanudjaja, Rahmiati. "Anugerah Demi Anugerah Dalam Spiritualitas Kristen Yang Sejati.” Veritas, no. 2 (October) (2002): 171-182.

Zinnbauer, Brian J., Kenneth I. Pargament, Brenda Cole, Mark S. Rye, Eric M. Butter, Timothy G. Belavich, Kathleen M. Hipp, Allie B. Scott, and Jill L. Kadar. "Religion and Spirituality: Unfuzzying the Fuzzy." Journal for the Scientific Study of Religion 36, no. 4 (December 1997): 549. https://www.jstor.org/stable/1387689?origin=crossref.

Zinnbauer, Brian J., Kenneth I. Pargament, and Allie B. Scott. "The Emerging Meanings of Religiousness and Spirituality: Problems and Prospects." Journal of Personality (1999).

Zohar \& Marshall, and Jenny King. "SQ: Spiritual Intelligence: The Ultimate Intelligence." Psychology and Psychotherapy 75, no. January (2002): 116-117.

"What Is Christian Religious Education?" Essay, UK. Last modified 2018. Accessed December 31, 2019. https:/www.ukessays.com/essays/religion/the-definition-ofchristian-religious-education-theology-religion-essay.php?vref=1. 